\title{
Withdrawn notice: 'Isolation and preliminary screening of biosurfactant producing bacteria from oil contaminated soil' [Braz. J. Biol. Sci. (2016), vol. 3, no. 6, p. 285-292]
}

Sidra Zafar ${ }^{1}$, Amna Shafiq ${ }^{1 *}$, Sayyada Ghufrana Nadeem² and Shazia Tabassum Hakim ${ }^{1}$

${ }^{1}$ Department of Microbiology, Jinnah University for Women, Karachi - 74600, Pakistan. *Email: amna.shafiq@live.com.

${ }^{2}$ Medical Mycology Research \& Reference Laboratory, Department of Microbiology, Jinnah University for Women, Karachi - 74600, Pakistan.

This article has been withdrawn at the request of the authors. The Editor-in-Chief and Publisher apologizes for any inconvenience this may cause.

This is a notice of withdrawn of the article: "Isolation and preliminary screening of biosurfactant producing bacteria from oil contaminated soil”, by Sidra Zafar, Amna Shafiq, Sayyada Ghufrana Nadeem and Shazia Tabassum Hakim, published in the Braz. J. Biol. Sci. (2016), vol. 3, no. 5, p. 285-292, https://doi.org/10.21472/bjbs.030605, at the request of the correspondent author.

Received

March 30, 2019

Accepted April 5, 2019

Released April 30, 2019

Open Acess Full Text Article

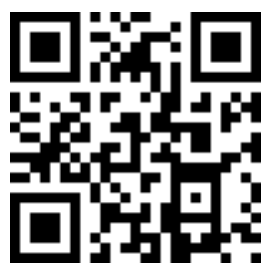

